\title{
Food Quality Control: History, Present and Future
}

\author{
Ihegwuagu Nnemeka Edith ${ }^{1}$ and Emeje Martins Ochubiojo ${ }^{2}$ \\ ${ }^{1}$ Agricultural Research Council of Nigeria \\ ${ }^{2}$ National Institute for Pharmaceutical Research and Development \\ Nigeria
}

\section{Introduction}

Food is any substance which when consumed provides nutritional support for the body. It may be of plant or animal origin, containing the known five essential nutrients namely, carbohydrates, fats, proteins, vitamins and minerals. Usually after consumption, food undergoes different metabolic processes that eventually lead to the production of energy, maintenance of life, and/or stimulation of growth (Aguilera 1999). The history of early man shows that, people obtained food substances through hunting, gathering, and agriculture. The assurance and protection of food quality has always been important to man. This is evident from the fact that, one of the earliest laws known to man was that of Food. Right from the Garden of Eden, there was a law guiding the consumption of food. In our time too, governments over many centuries have endeavoured to provide for the safety and wholesomeness of man's food by legal provisions, (Alsberg 1970; Jango-Cohen 2005). In spite of these provisions, adulteration of foods has increased and the detection of these adulterants has proved more difficult, essentially because of the sophisticated methods being used in the adulteration. The birth of modern chemistry in the early nineteenth century made possible the production of materials possessing properties similar to normal foods which, when fraudulently used, did not readily attract the attention of the unsuspecting consumer. However, modern analytical techniques are now available to detect adulterants in foods. In this modern age, most of the food consumed by man and animals alike is supplied by the food industry. The food industry is operated at different levels by either local, national or multinational corporations, that use either subsistence or intensive farming and industrial agriculture to maximize output. Whichever applies the importance of ensuring the quality of food and food products from the food industry cannot be over emphasized. In this chapter, we look at past and present attempts by scientists, individuals and/or governments to control food quality and prospect what the future might be.

\section{Food quality control}

Quality control is the maintenance of quality at levels and tolerance limits acceptable to the buyer while minimizing the cost for the vendor. Scientifically, quality control of food refers to the utilization of technological, physical, chemical, microbiological, nutritional and sensory parameters to achieve the wholesome food. These quality factors depend on specific 
attributes such as sensory properties, based on flavor, color, aroma, taste, texture and quantitative properties namely; percentage of sugar, protein, fibre etc. as well as hidden attributes likes peroxides, free fatty acids, enzyme (Adu-Amankwa 1999; Radomir 2004,Raju and Onishi 2002;).

Although, quality attributes are many, not all need to be considered at every point in time for every particular product. It is important to always determine how far relatively a factor is in relation to the total quality of the product. The quality attribute of a particular product is based on the composition of the product, expected deteriorative reactions, packaging used, shelf life required and the type of consumers. The most important element and ultimate goal in food quality control is protecting the consumer. To ensure standardization of these procedures, food laws and regulations cover the related acts affecting the marketing, production, labeling, food additive used, dietary supplements, enforcement of General Manufacturing Practice (GMP), Hazard Analysis and Critical Control Point (HACCP), federal laws and regulations, factory inspections and import/export inspections (Adamson 2004; Gravani 1986, Lasztity et al, 2004, Roe 1956 ).

\section{Importance of food quality control (QC)}

The most important quality factor of processed food is safety and reliability followed by "deliciousness" and "appropriate price" (Raju and Onishi 2002). The colossal loss a food industry will record if defective products were rejected or recalled, as well as the damaging effect on the company's image and public trust justifies the need for food quality control. For this reason, quality assurance should be a corporate goal, and should stem from the uppermost management level to the least staff of the industry. The Plan, Do, Check, Action (PDCA) cycle should be used when quality control is implemented.

\section{History of food quality control}

Many years ago, about 2500 years BC Mosaic and Egyptian laws had provisions to prevent the contamination of meat. Also, more than 2000 years ago, India already had regulations prohibiting the adulteration of grains and edible fats. In the actual sense, the laws of Moses contained decrees on food that are quite similar to certain aspects of modern food laws. Books of the Old Testament prohibited the consumption of meat from animals that died other than those intentionally slaughtered, perhaps consciously or otherwise, this was to ensure that contaminated meats were not consumed. There were also regulated weights and measures in foods and other commodities. Other ancient food regulations are referred to in Chinese, Hindu, Greek, and Roman literatures. Early records according to Lasztity et al (2004), classical writers also referred to the control of beer and inspection of wines in Athens, "to ensure purity and soundness of these products." The Roman government also provided state control over food supplies to protect consumers against bad quality and fraud. Even when most traders prefer to deal honestly and fairly, history has shown the need to ensure quality as evident by laws to protect purchasers and honest traders against those who refuse to adhere to accepted codes of good practice. It has been found (Adamson 2004) that, when food was scarce, resulting in expected increase in demand, fraudulent practices were prevalent.

\subsection{The middle ages}

This was the era of formation of trade guilds, especially the European communities with their powerful influence on the regulation of commerce (Petró-Turza and Földesi 2004). 
These were groups of tradesmen of particular specialties whose purpose was to provide control and general supervision over the honesty and integrity of their members and the quality of their products. For example, in 1419, a proclamation was issued prohibiting the adulteration or mixing of wine from different geographical areas (Adamson 2004). Many countries had their own peculiar way of controlling food quality. For example, in 1649 a Commonwealth statute was enacted to regulate the quality of butter (Petró-Turza and Földesi 2004). In France the most interesting and complete economic document of the Middle Ages available on the subject is the Livre des Métiers, which, in the thirteenth century, outlined a code of the comparative practices of the trade guilds of Paris.

By the seventeenth and eighteenth centuries, chemistry was being used as an analytical tool in the fight against food adulteration. Robert Boyle, using the principles of specific gravity, established the foundation for the scientific detection of the adulteration of food (Adamson 2004). Not much has changed, just the degree and level of sophistication of fraud, and the analytical techniques used to detect it.

\subsection{Industrial revolution in the nineteenth century}

Records (Roe1956; Alsberg 1970) show that, there were some sporadic standardization activities in ancient cultures and during the middle ages, a more organized standardization however, actually developed in the second half of the nineteenth century. This was when the industry reached a state of development and it was obvious that, unification was indispensable for large projects such as the railway. Efforts were made to find uniform measures for length and weight, but the meter and kilogram were not accepted as those standards until 1870s (Roe1956; Alsberg 1970). The period of industrial revolution was a time of tremendous expansion in many fields, which had a particular bearing on food production, regulations, and control too. Rapid changes from a rural to an urbanized society and from a domestic to a factory production system placed a strain on food production and distribution. Expectedly, the period created many public health problems, particularly in the industrialized centres, which were ill prepared to accommodate the masses that flocked to them. There was much poverty, and the uncontrolled development of industrial towns led to appalling conditions similar to those which can still be seen in urban areas in some parts of the world today. There were attendant calls for reform and improvements in matters relating to public health including essential food supplies within the crowded and unhygienic industrial centres (Petró-Turza and Földesi 2004). In England in 1820, Friederich Accum's A Treatise on Adulteration of Foods and Culinary Poisons highlighted the fraudulent practices that endangered public health. Unfortunately, at that time, the knowledge and understanding of hygiene and the dangers of food adulteration was so low and limited that this work was not considered. Many earlier papers that tried to draw attention to the adulteration of some foodstuffs were also been disregarded (Industrial Revolution $6^{\text {th }}$ edn. 2004).

Worthy of note however, was the setting up of a municipal service for the control of foodstuffs and beverages in Amsterdam in 1858. This was closely followed in England 1860, by the enactment of the first comprehensive modern food law in the world; "An Act to Prevent the Adulteration of Food and Drink." In addition to this being the first such act, it provided for a scientific approach to food problems by the appointment of an analyst whose sole duty, was "to examine the purity of articles of food and drink." (FAO 1999). 
Seven years later in Budapest, Hungary, a municipal service was set up for control of drinking water, this culminated in the establishment of an institute for control of food. During this period, similar types of laws appeared in Belgium, Italy, Austria, Hungary, and the Scandinavian countries. This was also a period of the foundation of institutions serving food inspection and food quality control. To give an idea of the volume of activity of such institutions, it may be mentioned that, according to a report from the Food and Drug Inspection of the State Board of Health of Massachusetts, since the passage of the law in 1882 until 1907, more than 176000 food samples were controlled, and more than 11000 were found to be adulterated. Although the main food control activity at this time was in the industrialized nations of Western Europe, many other countries such as Australia, Canada, and the US also enacted food laws. Although Australia did not enact a national food law, each state had the power to enact food laws and has remained ever since (Alsberg 1970; Hutt\& Merril 1991).

\subsection{The twentieth century}

The most prominent and substantive development at this period took place in India. The country amended its food adulteration control to ensure the purity of articles of food sold throughout the country between 1919 and 1941. In 1954, India enacted the Prevention of Food Adulteration Act and this Act, with its later amendments, is still in force (Roe 1956; Lasztity 2004). In the Far East, food control was slow to appear, and it was not until the 1940 s or as late as the 1960s that food control measures were introduced. During this period, many Latin American countries also enacted food laws, even though the legal systems of most Latin American nations are based upon those of Spain and Portugal, significant differences have developed in their food laws. Efforts are now being made to harmonize these differences.

In Africa, food laws were of little significance until the second half of the twentieth century Lasztity et al (2004). Independent states that started to emerge in the late 1950s were influenced in many matters, including food control services, by the European countries with which they had been closely associated (Petró-Turza and Földesi 2004). For example, French territories had developed French food enactments, while British territories followed British procedures. Food legislation was often inherited in total by the newly independent states. Although it is obvious that, there is the need for major adjustments today as situations now are quite different from those for which the enactments had originally been designed, several factors ranging from corruption to lack of visionary leadership has contributed largely to the inability of many African countries to make reasonable headway. This is beyond the scope of this book. Worthy of mention however, is the great lack of skilled or trained personnel in developing countries to draw up food laws suited to the nation's particular circumstances, or the scientific or technical staff necessary for food analysis, sampling, and efficient inspection (Lasztity et al, 2004). There is also a shortage of materials and equipment, and many other problems connected with the inauguration and operation of an effective food control system.

\section{The food supply chain}

The food supply chain is a net chain that food moves along the peasant household, the processing industry, the distribution centre, the wholesaler, the retailer as well as consumer 
(Thirupathi 2006). In general, the food supply chain is composed of five links: product material supplying link, the production processing link, the packing storage and transporting link, the sale link and the consumer expending link with each link involving related sub-links and the different organization carriers.

The supply chain is a networked structure, composed of flow of the physical, the information, the finance, the technical, the standardized, the security and the value-added connections (Grunert 2005; Thirupathi 2006).

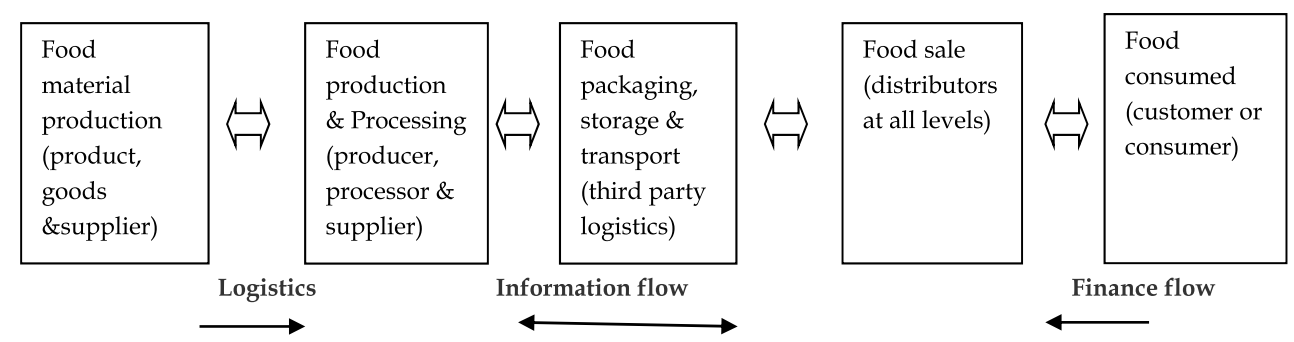

Fig. 1. Food supply chain basic structure (Thirupathi 2006)

\subsection{Quality procedures}

Along the supply chain, food is unavoidably exposed to numerous hazards. Therefore, knowing the risk factors at each phase of the supply chain assists in ensuring that an effective and comprehensive quality system is put in place. To guarantee food quality, it is important to ensure that, all the steps of the supply chain are carried out strictly, with care, and according to the standard operating procedures. At each phase of the supply chain, the potential risks, responsibilities, and how they can best be addressed must be fully explored.

\section{Food contamination}

Contamination of food can occur at any of the phases of the food supply chain and these will be expounded under the following broad categories:

1. Physical

2. Chemical

3. Microbiological

4. Other contaminants

\subsection{Physical contamination}

One of the major physical contaminations is adulteration. It is the mixing of inferior quality material with the superior product, thereby reducing the nature, quality and originality in taste, color, odor and nutritional value and ultimately causing ill effects on the health of the consumer (Thirupathi 2006). The main motive of adulteration and of course the "adultratee" is to gain undue advantage and most often profits. Almost all the food stuffs being sold in the market are prone to adulteration, but main food products that are often heavily adulterated are spices, milk products, edible oil, beverages drinks, sweets, pulses, sugar, processed foods, rice and cereal products like flour. The table below shows some common foodstuff and their adulterants (Lucey 2006). 
Types of Foodstuff

Milk and Milk products

Butter and Ice cream

Vegetable Oils and Fats

Dry Beverages

Wet Beverages

Spices and Condiments

Cereals and their products.

Pulses and their products.

Miscellaneous Items
Main adulterants
Water, refined oil, separated (cream less) skim milk, solution, flours, animal fats, starch, dextrin.

Hydrogenated fats and animal fats, Artificial sweeteners,jelling agents, other fats, water nut flour, non permitted colours

Coffee Powder Exhausted Coffee powder, starch, roasted dates, tamarind seeds, tea residues, other leaves with added color

Coffee Powder Exhausted Coffee powder, starch, roasted dates, tamarind seeds, tea residues, other leaves with added color

Spurious narcotics and other concentrated liquids, Artificial sweeteners (Saccharin), mineral acids, Colored invert sugar, high concentrated sugar solution, Cheap liquids, wine and beer water and juices.

Whole turmeric Coating with lead chromate or coal tar dye starch or talc colored yellow with coal tar dye, Starch colored brown with coal tar dye, Coriander seed Other green colored seeds Powdered bran or sawdust colored green with dye, Starch colored red with coal tar dye, Argemone seeds, Artificial cumin seed like product, Dried papaya seeds and other plant gums.

Wheat Stones, straws, low variety grains,Talc, chalk powder, tapioca flour, Maize flour, low variety rice and semolina.

Yellow maize flour and Tapioca flour.

Seeds or nuts broken and colored, Pickle, jam, chutney and squash of cheap products. Also Sweets Artificial sweeteners and tapioca flour.

Table 1. List of common foodstuffs and their adulterants 


\subsection{Chemical contamination}

Chemicals, which elicit harmful effects when consumed by animals or humans, are said to be toxic. The use of chemicals in the production and processing of food and food products not only affects the quality, but also disguises the deterioration and constitutes deliberate adulteration which is potentially very harmful to the health (Wilm 2003). It is advised that food additives like colouring matter, preservatives, artificial sweetening agents, antioxidants, emulsifiers/stabilizer, flavors/flavouring enhancers etc., if used should be of approved quality and processed under good manufacturing practices.

\begin{tabular}{ll}
\hline Types of Foodstuff & $\begin{array}{l}\text { Main adulterants } \\
\text { (Chemical formula and type) }\end{array}$ \\
\hline Fish ,Meat \& Dairy Products, & PCBs (polychlorinated biphenyls) \\
Eggs and Poultry. & $\begin{array}{l}\text { Juice Production and flavourings (multiple } \\
\text { organic acids) }\end{array}$ \\
Citrus and other fruits & Dichloropropane $\left(\mathrm{CH}_{3} \mathrm{CHClCH}_{3} \mathrm{Cl}\right)$. \\
Oil and fat solvents & Ethanol $\left(\mathrm{CH}_{2} \mathrm{CH}_{2} \mathrm{OH}\right)$. \\
Alcohol Beverages & 3-MCPD \\
In Asian-style sauces such as soy, oyster, & (3-monochloropropane-1,2-diol) \\
mushroom sauces, etc. & Glycoalkaloids $(\mathrm{GA})$ \\
Potato tubers. & Deoxynivalenol (Vomitoxin) \\
Unclean soft wheat for use. in non-staple & \\
foods and baby foods & \\
Fruit brandies and liqueurs, wines, & Ethyl carbamate \\
distilled spirits. & \\
\end{tabular}

Table 2. List of chemical adulterants in food

\subsection{Microbiological contamination}

Microbiological contamination of food is perhaps the most prevalent health problem in the contemporary world (Wilm 2003; Thirupathi 2006). To ensure good quality and safe food therefore, microbiological criteria should be established and freedom from pathogenic microorganisms must be ensured, including the raw materials, ingredients and finished products at any stage of production/processing. Accordingly the microbiological examination of the foods products has to be adopted widely. The microbiological criteria must be applied to define the distinction between acceptable and unacceptable foods (Thirupathi 2006). Food poisoning often results from the consumption of old, used, residual, fermented or spoiled food, as these may be contaminated with bacteria or other microorganisms, hence toxic. Infants and children are more susceptible to food poisoning and care should always be taken when giving them food. Gastroenteritis is caused by food contaminated with the enterococcus, streptococcus faecalis, which is frequently found in the human intestinal tract (Thirupathi 2006). Food poisoning may also be caused by inadequately refrigerated food contaminated with microorganisms such as Clostridium perfringens which grows well in the alimentary canal producing the poisoning within 8-12 hours after the ingestion of contaminated food. (Wilm 2003). Bacillus cereus, a gram positive, aerobic, spore-forming organism has been reported to be the etiologic agent in numerous 
food poisoning outbreaks. Some of the fatal effects of microbial contamination of food include; liver cancer is which is high in some countries due to aflatoxin. Flavism (hemolytic anemia) is caused by eating broad beans or by inhaling the pollen of its flower. In severe cases death may occur within 24-48 hours of the onset of the attack. Lathyrism is a disease, which paralyses the lower limbs (Thirupathi 2006).

\subsection{Other contaminants}

Metals are one of the many unintentional contaminants of food. When present beyond trace amounts, they are toxic. They find their way into food through air, water, soil, industrial pollution and other routes including food utensils. Common examples include, enamelware of poor quality which contributes antimony and galvanized utensils leaching zinc (Thirupathi 2006). A major source of tin contamination is tin plate, which is used for making containers for all types of processed foods. It has been shown that, a small quantity of metal is added when food is cooked in aluminum utensils (Wilm 2003). Although, copper is an essential trace element required by the human body, but copper-contaminated food is toxic. Fumigants used to sterilize food under conditions in which steam heating is impractical contaminate food. This is because, they may react with food constituents to produce or destroy essential nutrients. For example, ethylene oxide, a commonly used fumigant, reacts with inorganic chloride to form ethylene chloro hydride, which is toxic (Wilm 2003; Thirupathi 2006). Some solvents like trichloro ethylene used for the extraction of oil from oil seeds react with the foodstuff being processed resulting in the formation of toxic products.

During processing of food, lipids may undergo numerous changes on prolonged heating, oxidative and polymerization reactions could take place, thereby decreasing the value of the processed products.

Smoking of meat and fish for preservation and flavouring is an old practice. But this processing contaminates the food with polycyclic aromatic hydrocarbons such as benzopyrene, many of which are carcinogenic.

Lubricants, packing materials etc. also contaminate foods.

A number of chemicals are intentionally added to foods to improve their nutritional value, maintain freshness, impact desirable properties or aid in processing. They also contaminate food if excessive in quantity (Thirupathi et al, 2006).

\section{Methods of food quality control}

In addition to ensuring safe and health food for the consumer, product manufacturers and service industries have realized that competition in a global market require a continual and committed effort towards the improvement of product and service quality. Therefore, they follow the process improvement cycle comprising PLAN (plan improvement), DO (implement plan for improvement), CHECK (analyze collected data) and ACT (take action). Quality control process consists of raw materials, in-process, product and service. The major factors in process that cause variability in quality of finished product are people, equipment and methods or technologies employed in the process. Use of proper statistical process control methods is also vital for assurance of the product quality. Usually, the value of quality characteristics is used to provide feedback on how processes may be improved. Statistical quality control comprises the following procedure: 
a. Finished product is measured

b. Sampling occurs for days or weeks

c. Lot is either accepted or rejected based on information from sample

Contrary to statistical quality control, statistical process control methods focus on identifying factors in process that cause variability in finished product, eliminating the effect of these factors before worse product is manufactured, and control charts give on-line feedback of information about process. (Raju 2002). Food quality control measures have continuously improved since the 20th century, owing largely to the implementation of good practices, quality systems and increased traceability in food production. Ever since microorganisms were discovered in our environment and linked to typhoid fever and other diseases that have plagued humanity, public health authorities have been concerned with the accumulation of filth and foul odours in urban areas (Raju 2002). The first early inspection systems based on sensory evaluations were legally enforced at the beginning of the 20th century. Initial bacteriological techniques to detect pathogenic bacteria in foods, such as shellfish, appeared soon after (Raju 2002). From that point on, the food and beverage industry has applied stricter product inspection procedures and more and more effective production methods to conserve the freshness of natural raw materials. Today, the establishment of good manufacturing practices (GMP) and good hygienic practices (GHP) in many countries has significantly reduced the risk of spoilage and pathogenic microorganisms in modern food products. In addition to complying with national and international food regulations, food manufacturers are required to follow international quality standards, such as ISO as well as the Hazard Analysis Critical Control Point (HACCP) system.

In recent years, there has been an increasing focus on traceability in food production (Raju 2002). This has followed public concerns arising from cases of food contaminations and the development of foods containing ingredients derived from genetically modified (GM) crops. In the light of the increasing need for food more rapid food testing, it became clear that, the traditional microbiological detection and identification methods for food borne pathogens was no longer effective, because, it was time consuming and laborious to perform, and are increasingly unable to meet the demands for rapid quality control. A rapid method is generally characterized as a test giving quicker results than the standard accepted method of isolation and biochemical and/or serological identification (Raju 2002). Some of the newer and more rapid methods of food quality control are:

\subsection{Ion mobility spectrometry (IMS) or differential mobility spectrometry (DMS)}

These methods are used in the identification and quantification of analytes with high sensitivity. The selectivity can even be increased - as necessary for the analyses of complex mixtures - using pre-separation techniques such as gas chromatography or Multi-Capillary Columns (MCC). The method is suitable for application in the field of food quality and safety -including storage, process and quality control as well as the characterization of food stuffs (Vautz 2006).

\subsection{Electronic-nose}

This is an instrument which comprises an array of electronic chemical sensors with partial specificity or broad-band chemical selectivity and an appropriate pattern recognition system, capable of recognizing simple or complex odours (Gardner and Bartlett's 1994). This 
method is used to detect the bacterial growth on foods such as meat and fresh vegetables. It can also be used to test the freshness of fish. It is used in the process control of cheese, sausage, beer, and bread manufacture as well as for detection of off-flavors in milk and dairy products. This technique has other applications too. The advantages of the electronic nose can be attributed to its rapidity, objectivity, versatility, non requirement for the sample to be pretreated and ease of use Natale et al (1997).

\subsection{Immunochemical methods}

This method is based on antigen - antibody interaction. The antibodies are highly specific for the antigen (analyte), and secondly, the antigen, the antibody, or an antiglobulin may be conjugated to an enzyme that produces an intensely colored or fluorescent product in the presence of the enzyme substrate to enhance the detectability of the analyte in an amplification step. Toxins produced by E. coli, Clostridium, Salmonella and Shigella have also been similarly detected (Mason et al, 1961).

\subsection{Enzyme Immunoassay (EIA)}

Microorganisms are often characterized and identified by the presence of unique protein carbohydrate markers also called antigens, located within the body or the flagella of the cell (Greiner and Konietzny, 2008). Detection of these unique antigens has been a cornerstone of diagnostic microbiology for many years. In recent years, EIA using monoclonal antibodies have made available rapid and consistent microbiological detection systems. The most widely used systems employ a sandwich technique using antibody attached to a polystyrene matrix to which the sample is added. Post incubation, a second antibody, which is specific for the organism and has been tagged with an enzyme, is added. The addition of enzyme substrate to the mixture completes the EIA. The presence of the specific organism results in a colorimetric change in the enzyme substrate, which may be observed visually or with a spectrophotometer. Most EIA are very specific but lack sensitivity. Normal sensitivity has been reported to be in the range of $106 \mathrm{org} / \mathrm{ml}$ (Greiner and Konietzny, 2008).

\subsection{Biosensors}

Biosensor is usually a device or instrument comprising a biological sensing element coupled to a transducer for signal processing (Songa et al, 2009). Biological sensing elements include enzymes, organelles, antibodies, whole cells, DNA, and tissues. There are different types, conductance bioluminescence enzyme sensors utilizing potentiometric, amperometric, electrochemical, optoelectric, calorimetric, or piezoelectric principles. Basically, all enzyme sensors work by immobilization of the enzyme system onto a transducer (Songa et al, 2009). This technique provides sensitive, miniaturized systems that can be used to detect unwanted microbial activity or the presence of a biologically active compound, such as glucose or a pesticide in food. Immunodiagnostics and enzyme biosensors are two of the leading technologies that have had the greatest impact on the food industry (Greiner and Konietzny, 2008).

\subsection{Flow cytometry (FCM)}

Specific detection of pathogenic strains can be achieved by Flow cytometry using immunofluorescence techniques, which allow microorganism detection at the single-cell 
level. Although this technology can be used for food samples, it requires prior isolation of the target organism to generate antibodies (Comas-Riu, 2009). FCM finds wide application in milk and brewing quality control. The advantage of FCM is that it can also differentiate Viable Non-Culturable (VBNC) form of bacteria from healthy cultivable cells (Comas-Riu, 2009). This technology has the ability to detect microorganisms at relatively low concentrations in a short time, while multiple labeling allows the detection of different organisms or different stages in the same sample (Comas-Riu, 2009).

\subsection{Polymerase chain reaction (PCR)}

This technique involves the following steps: Isolation of DNA from the food, amplification of the target sequences, separation of the amplification products by agarose gel electrophoresis, estimation of their fragment size by comparison with a DNA molecular mass marker after staining with ethidium bromide and finally, a verification of the PCR results by specific cleavage of the amplification products and by restriction endonuclease or southern blot. Alternatively amplification products may be verified by direct sequencing or a second PCR (Greiner and Konietzny, 2008).

\subsection{Pulsed-field gel electrophoresis (PFGE)}

PFGE is a restriction-based typing method that is considered by many to be the "gold standard" molecular typing method for bacteria (Greiner and Konietzny, 2008). In this electrophoretic approach, DNA fragments are separated under conditions where there is incremental switch of the polarity of the electric field in the running apparatus. This technique allows for the resolution of DNA fragments up to $800 \mathrm{~kb}$ in size. When DNA is restricted with a restriction enzyme, PFGE provides a DNA "fingerprint" that reflects the DNA sequence of the entire bacterial genome. PFGE is a widely accepted method for comparing the genetic identity of bacteria (Greiner and Konietzny, 2008). PFGE typing has demonstrated a high level of reproducibility for food borne pathogens. A major advantage of this method is its universal nature making it useful in bacteria sub typing, however, its limitation is that it is time consuming.

\subsection{Magnetic separation}

One of the typical applications of this technique was reported by Mattingly (1984) \& Safarik (1995). The author separated salmonella from food and faecal matter using myeloma protein and hybrid antibody (for $\mathrm{O}$ antigen), conjugated to a polycarbonate- coated metal bead. It has also been reported (Haik et al, 2008) that, Food sample like milk, yogurt, meat and vegetables can be tested. The challenge is in detecting $E$. coli is in the isolation of pathogenic strain from nonpathogenic strains. Immunomagnetic detection of listeria monosytogens has also been reported by Skjerve et al. (1990). While Johne et al (1989) using magnetic beads coated with polyclonal antibodies was able to detect and isolate the specific protein of $s$. aureus.

\section{Near-infrared (NIR) spectroscopy}

NIR has proven to be an effective analytical tool in the area of food quality control. The key advantages of NIR spectroscopy are (1) its relatively high speed of analysis, (2) the lack of a need to carry out complex sample preparation or processing, (3) low cost, and (4) suitability 
for on-line process monitoring and quality Control. The disadvantage of this method includes the requirement for large sample sets for subsequent multivariate analysis. (Michelini 2008; Cozzolino 2008). Recently, researchers at Zhejiang University in Hangzhou, China used Vis/NIR spectroscopy together with multivariate analyses to classify nontransgenic and transgenic tomato leaves (Xie et al, 2007).

\subsection{X-ray}

This is a relatively newer technology in food quality control. $X$-rays started making in-roads into the food industry in the early 1990s. The driving force behind this was the increasing number of foreign bodies which could not be identified by metal detectors. Other than contaminants like glass, bone, rubber, stone or plastic, some specific applications are also more challenging for metal detectors, such as fresh meat and poultry, or foil-wrapped products (Ansell 2008). X-ray inspection has considerable advantages in many food and beverage processing environments in that, it is easy to install, safe and simple to use, even without previous experience. It quickly and consistently identifies substandard products, reducing product recall, customer returns and complaints, therefore protecting manufacturers' brands and most importantly, preventing ill health.

\subsection{Computer vision}

Aguilera et al (2006) reported a computer system that consisted of four basic components: the illumination source, an image acquisition device, the processing hardware, and suitable software modules. Their study was focused on analyzing the relevance of computer vision techniques for the food industry, mainly in Latin America. The authors described how the use of these techniques in the food industry eliminates the subjectivity of human visual inspection, adding accuracy and consistency to the investigation. They also reported that, the technique can provide fast identification and measurement of selected objects, classification into categories, and color analysis of food surfaces with high flexibility. They opined that, since the method was non-contact and non-destructive, temporal changes in properties such as color and image texture can also be monitored and quantified.

\section{Some recent reports on food quality control}

\subsection{Livestock}

Nardone (2002) found that the meat and milk characteristics are more related with human health and with some factors affecting their quality. They used various techniques to control meat characteristics. The Molecular biology techniques was of great interest to the author as it gave insight to new product certification viz, species, breed, animal category (age, sex, etc). He also reported that milk quality may be influenced by some innovative technology among which is the Automatic Milking Systems (AMS). AMS increases milk yield and milking frequency from twice to three times or more per day requiring a minimum extra amount of labour, however, contradictory results are reported about the effects of AMS on milk quality. Several authors found that after the introduction of AMS milk quality decreased, particularly fat, proteins percentage while total bacterial plate count, SCC, freezing point and the amount of free fatty acids increased significantly. Nardone (2002). Aguilera et al, (2006) reported the usefulness of vision Q-Lab to assess the quality of food Samples. The system consists of a highly general hardware setting, able to support different 
applications, and highly modular software, easily adapted to the measurement needs of diverse food products. The main results of this application, was to classify rice grains and lentils (Aguilera et al, 2006). Grain quality attributes are very important for all users and especially the milling and baking industries. An earlier report by Zayas et al (1996) showed the usefulness of machine vision to identify different varieties of wheat and to discriminate wheat from non-wheat components. In his own report, Katsumata (2007) showed that, visible light Photoluminescence (PL) peaking at around $\lambda=460 \mathrm{~nm}$ is characteristic of cereals, such as rice, wheat, barley, millet, flour, corn starch, peanut, under illumination of ultra-violet light at $\lambda=365 \mathrm{~nm}$. They further reported that Peak intensity of PL and Distribution of PL intensity varies with variety and source of the specimens which was found to be fitted with a Gaussian curve. Visible light PL is suggested to be potentially useful technique for the non-destructive and quick evaluation of the cereals and other starchy products. Songa (2007) reported the use of amperometric nanobiosensor for determination of glyphosate and glufosinate residues in corn and soya bean samples. The author found that biosensor has the features of high sensitivity, fast response time (10 to 20 s) and long term stability at $4^{\circ} \mathrm{C}\left(>1\right.$ month). Detection limits was in the order of $10^{-10}$ to $10^{-11}$ $\mathrm{M}$ for standard solutions of herbicides and the spiked samples. The author found that herbicide analyses can be spiked on real samples of corn and soy beans, corroborating that the biosensor is sensitive enough to detect herbicides in these matrices.

\subsection{Fruits, vegetables and nuts}

Narendra and Hareesh (2010) observed that Computer vision has been widely used for the quality inspection and grading of fruits and vegetables. It offers the potential to automate manual grading practices and thus to standardize techniques and eliminate tedious inspection tasks. The capabilities of digital image analysis technology to generate precise descriptive data on pictorial information have contributed to its more widespread and increased use. Aranceta-Garza et al (2011) reported a PCR-SSCP method for the genetic differentiation of canned abalone and commercial gastropods in the Mexican retail market. Their study was aimed at creating molecular tools that can differentiate abalone (Haliotis spp), from other commercial fresh, frozen and canned gastropods based on18S rDNA and also identify specific abalone product at the species level using the lysine gene. The authors found that the methods were reliable and useful for rapid identification of Mexican abalone products and could distinguish abalone at the species level. The methods could genetically identify raw, frozen and canned products and the approach could be used to certify authenticity of Mexican commercial products or identify commercial fraud. Lehotay (2011) reported the qualitative analysis of pesticide residues in fruits and vegetables using fast, low-pressure gas chromatography - time of flight mass spectrometry (LP-GC/MS). The author demonstrated that, to increase the speed of analysis for GC-amenable residues in various foods and provide more advantages over the 40 traditional GC-MS approach, LPGC/MS on a time-of-flight (ToF) instrument, which provides high sample throughput with $<10 \mathrm{~min}$ analysis time should be applied. The method had already been validated to be acceptable quantitatively for nearly 150 pesticides, and in this study of qualitative performance, 90 samples in total of strawberry, tomato, potato, orange, and lettuce extracts were analyzed. The extracts were randomly spiked with different pesticides at different levels, both unknown to the analyst, in the different matrices. They compared automated 
software evaluation with human assessments in terms of false positive and negative results only to found that the result was not significantly different. Mustorp (2011) reported a robust ten-plex quantitative and sensitive ligation-dependent probe amplification method, the allergen- Multiplex, quantitative ligation-dependent probe amplification (MLPA) method, for specific detection of eight allergens: sesame, soy, hazelnut, peanut, lupine, gluten, mustard and celery. Ligated probes were amplified by PCR and amplicons were detected using capillary electrophoresis. Quantitative results were obtained by comparing signals with an internal positive control. The limit of detection varied from approx. 5 to 400 gene copies depending on the allergen. The method was tested using different foods spiked with mustard, celery, soy or lupine flour in the 1-0.001 \% range. Depending on the allergen, sensitivities were similar or better than those obtained with PCR.

\section{Conclusions}

Without doubts, there is a need for continuous improvements in rapid diagnostic methods, analytical techniques as well as visionary and computational equipments required for food quality control of the future. For example, as it stands today, only about $41.5 \%$ of microbiology tests utilized rapid methods. The growth of diagnostic industry should result in increased rapid tests in the nearest future and this should result in improved performance. It is expected that, there will be significant economic benefits and the ability to practice proactive and risk prevention food safety programs. In fact various schools of thoughts have it that, by 2015, the companies should be able to utilize automation technology to screen incoming raw materials and in-process parameters with near real-time information; physical, chemical or biological, while utilizing these newer methods. With automation, time is saved and productivity increases. In this regard, the two main traditional and rapid methods: flow cytometry to provide the total microbial count rapidly and polymerase chain reaction (PCR) to detect microorganisms both quickly and specifically will continue to grow in the near future. Although some of these automated newer technologies are extremely rapid, there have been questions about their sensitivity. Some investigators agree that, the instruments can produce results in seconds, but they opine strongly that they are not sensitive enough. As instrument companies today are working to provide the best combination of speed and sensitivity, the challenge of the future still lies with their ability to produce one instrument combining accuracy, rapidity and sensitivity while ensuring that, the entire control process still ensures a minimal risk of contamination. In the nearest future, the mass spectrometry may be needed in food quality control. It is already proofing useful identifying unknown compounds, antibiotics and pesticides in raw materials and in detecting trace metals in foods. DNA-based assays, instruments, and software, all designed to work together including the emerging area of bioinformatics; sequencing, assay design, and chemical analysis are all capable of developing new ways for food quality control in the future. This chapter looked at the history, current and future of food quality control and also revealed a large number of approaches to enhancing food quality. It is therefore safe to conclude that, food quality control is an indispensable tool in the food industry. As enumerated above, the development of adequate, effective, rapid, and sensitive food quality control systems however, faces serious challenges driven by its capital intensive nature and sophisticated adulteration. While it may seem easier for the developed 
nations to match quality control with adulteration techniques, to make any meaningful progress in resource limited nations of the world, there is the need for collaborations between laboratories around the globe, just as it is necessary for regulatory agencies around the world to also collaborate both in sharing information and in technologies as well as capacity development. The existing legislations seem adequate, but implementation may be weak, there is need for international coordinated efforts to enforce the laws.

\section{References}

Adamson Melitta Weiss (2004): Food in medieval times, pp 64-67; Greenwood Publishing Group, 88 Post Road West, Westport, CT 06881.

Adu-Amankwa Pearl, (1999) Quality and Process Control in the Food Industry Food Research Institute, Published in The Ghana Engineer, http:// practicalaction.org/practicalanswers/

Aguilera, Jose Miguel and David W. Stanley,(1999): Microstructural Principles of Food Processing and Engineering, Second Edition Springer, ISBN=0834212560.

Alexandrakis D, Downey G, Scannell AG. ( 2008),Detection and identification of bacteria in an isolated system with near-infrared spectroscopy and multivariate analysis. $J$ Agric Food Chem; 56: 3431-7.

Alsberg. CL. ( 1970),Progress in Federal Food control In: Ravenel. MP.ed. A. Half century of Health. New york Times Pp. 211-220.

Ansell Tim: (2008) , X-ray a new force in food quality control, Al Hilal Publishing \& Marketing Group.

Augustin Scalbert, Cristina Andres-Lacueva, Masanori Arita, Paul Kroon, Claudine Manach, Mireia Urpi-Sarda, and David Wishart: (2011): Databases on food phytochemicals and their health promoting effects J. Agric. Food Chem., Just Accepted Manuscript Publication.

Chaplain CV, (1970).History of state \& municipal control of diseases In: Ravenel. MP, ed. A. Half century of Health, New york Arno Press and the New york Times: Pp 133-160

Codex Alimentarius Commission (1997), Report of the Twelfth Session of the Codex Committee on General Principles, ALINORM 97/33.

Comas-Riu Jaume, Núria Rius: (2009), Flow cytometry applications in the food industry; J Ind Microbiol Biotechnol 36: 999-1011.

Cozzolino D, Fassio A, Restaino E, Fernandez E, La Manna A. (2008). Verification of silage type using near-infrared spectroscopy combined with multivariate analysis. J Agric Food Chem.; 56: 79-83

FAO. (1998)FAO Technical Assistance Programme: Food Quality and Safety. (ESN internal publication), Rome.

FAO. (1999). FAO trade-related technical assistance and information. Rome. Food and Agriculture Organization of the United Nations. (2005), The State of Food Insecurity in the World.

Gravani, Robert B: (1986), How to Prepare A Quality Assurance Plan, Food Warehousing. Department of Health and Human Services, Public Health Service, U.S. Food and Drug Administration, Food Science Facts for the Sanitarian, Dairy and Food Sanitation. 
Greiner Ralf and Ursula Konietzny http://www.worldfoodscience.org/cms/?pid=1003869 Modern Molecular Methods (PCR) in Food Control: GMO, Pathogens, Species Identification, Allergens.

Haik Yousef et al (2008); MagneticTechniques for Rapid Detectionof Pathogens: Reyad M. Zourob et al. (eds.), Principles of Bacterial Detection: Biosensors, Recognition Receptors and Microsystems,. İ Springer Science+Business Media, LLC 2008.

Halász,Anna Radomir Lásztity, Tibor Abonyi, and Arpad Bata, (2009): Decontamination of Mycotoxin-Containing Food and Feed by Biodegradation Food Reviews International, volume 25, pp:284-298.

Handbook of organic food safety and quality, Edited by J Cooper, C Leifert, Newcastle University, UK and U Niggli, Research Institute of Organic Agriculture (FiBL), Switzerland, Woodhead Publishing Series in Food Science, Technology and Nutrition No. 148 n.d. http://quality.com/details/print/807365/December/January2009.html http://www.foodquality.com/mag/06012006_07012006/fq_06012006_SS1.htm

Hussain, M. A. ( 2010): Future insights: Proteomics a power technique to ensure food quality and safety; Proceedings China International Food Safety and Quality Conference, 10-11 Shanghai, PR China. p. 51.

Hutt, Peter Barton and Merrill Richard(1991): public health and the healthy public:a communitarian perspective on privatization and the FDA; Food and drug law, pp 614.

"Industrial Revolution," ( 2004), Columbia Encyclopedia, Sixth Edition, Copyright (c).

Jane Byrne: (2008): RFID temperature logger could enhance cold chain quality control, News on Food and Beverage Processing and Packaging.

Jango-Cohen, Judith; (2005):The History of Food; Twenty-First Century Books, ISBN 0-82252484-8, Minneapolis, Minn.

Janni J, Weinstock BA, Hagen L, Wright S. (2008): Novel near-infrared sampling apparatus for single kernel analysis of oil content in maize. Appl Spectrosc 62: 423-6.

Johne et al.: (1989);Imunomagnetic separation of s. aureus , J. Clin Microbiol, 27(7): pp; 16311635.

Katsumata T. , T. Suzuki, H. Aizawa and E. Matashige (2007): Photoluminescence evaluation of cereals for a quality control application, Journal of Food Engineering, Volume 78, Issue 2, Pages 588-590.

Klaus G. Grunert (2005): Food quality and safety: consumer perception and demand, European Review of Agricultural Economics Vol. 32 (3) pp. 369-391.

Lehotay Steven J., Urairat Koesukwiwat, Henk van 5 der Kamp, Hans G.J. Mol, and Natchanun Leepipatpiboo (2011): Qualitative Aspects in the Analysis of Pesticide Residues in Fruits and Vegetables using Fast, Low-Pressure Gas Chromatography Time-of-Flight Mass Spectrometry Low-pressure gas chromatography -mass spectrometry (LP-GC/MS Journal of Agricultural and Food Chemistry, just accepted manuscript.

Lucey John: (2006) "Management Should Serve as Role Models for Good Work Habits and Acceptable Hygienic Practices "Food Quality

Mattingly, J.A1. (984).: An enzyme immunoassay for the detection of all Salmonella using a ombination of a myeloma protein and a hybridoma antibody. Journal of Immunological Methods 73, 147-156. 
Michelini E, Simoni P, Cevenini L, Mezzanotte L, Roda A. (2008): New trends in bioanalytical tools for the detection of genetically modified organisms: an update. Anal Bioanal Chem 392: 355-67.

Moros J, Llorca I, Cervera ML, Pastor A, Garrigues S, de la Guardia M. ( 2008): .Chemometric determination of arsenic and lead in untreated powdered red paprika by diffuse reflectance near-infrared spectroscopy. Anal Chim Acta; 613: 196206

Nardone Alessandro (2002): Evolution of livestock production and quality of animal products, Proc. "39th Annual Meeting of the Brazilian Society of Animal Science" Brazil, 486-513.

Narendra V G and Hareesh K S (2010): Quality Inspection and Grading of Agricultural and Food Products by Computer Vision- A Review: International Journal of Computer Applications Volume 2 - No.1.

Natale Corrado Di et al (1997) ; Electronic-nose modelling and data analysis using a selforganizing map; Meas. Sci. Technol. 8 1236-1243.

Perrot. N.' . Ioannou, I. Allaisc, C. CurtJ. Hossenloppand G. Trystram (2006): Fuzzy Concepts Applied to Food Control Quality Control Fuzzy Sets and Systems Volume 157, Issue 9, pp, 1145-1154.

Potter, Norman N. and Joseph H. Hotchkiss, (1995): Food Science. 5th Edition. New York: Chapman \& Hall. pp. 90-112.

Quality Assurance / Control in Food Processing. Contained in: Food Fortification Technology and Quality Control. (FAO Food and Nutrition Paper - 60)

R.V. Sudershan, Pratima Rao and Kalpagam Polasa.( 2009): Food safety research in India: a review As. J. Food Ag-Ind. 2(03), 412-433.

Radomir Lasztity, Marta Petro-Turza, Tamas Foldesi (2004): History of food quality standards, in Food Quality and Standards, [Ed. Radomir Lasztity], in Encyclopedia of Life Support Systems (EOLSS), Developed under the Auspices of the UNESCO, Eolss Publishers, Oxford, UK.

Raju K. V. R.and Onishi Yoshihisa. (2002): Report of the APO Seminar on Quality Control for Processed Food held in the Republic of China, (02-AG-GE-SEM-02). This report was edited by. Raju K. V. R.

http//foodquality.wfp.org/qualityprocedure/tabid/119/.aspxdefault

Roe R.S. (1956): The food $\mathcal{E}$ Drugs Act- past,present $\mathcal{E}$ future in Welch H marti-Ibunez. F..eds. The impact of the food \& Drug Admin. on our society, New york : MD Publications Pp. 15-17.

Rust and Olson (1987): Coping With Recalls, Meat and Poultry Vol. No. 3, March.

Safarik.M, Safarikova,\&M.J.Forsethe. (1995): Application of Magnetic Separation in applied Microbiology; Journal of Applied Microbiology, 78, 575-585.

"Short Narratives: the Early Modern Agricultural Revolution," World History at KMLA, (2002) ;http://www.zum.de/whkmla/apeur/narratives/NarrativesAgrRev.html

Skjerve E, L M Rørvik and O Olsvik. (1990): Detection of Listeria monocytogenes in foods by immunomagnetic separation. Appl Environ Microbiol, 56(11): 3478-3481.

Songa Everlyne A., Vernon S. Somerset, Tesfaye Waryo, Priscilla G. L. Baker, and Emmanuel I. Iwuoha. (2009): Amperometric nanobiosensor for determination of glyphosate and glufosinate residues in corn and soya bean samples; Pure Appl. Chem., Vol. 81, No. 1, pp. 123-139. 
Stina Lund Mustorp, Signe Marie Drømtorp, and Askild Lorentz Holck: Multiplex. (2011): Quantitative ligation-dependent probe amplification for determination of allergens in food, J. Agric. Food Chem.Just Accepted Manuscript Publication .

Swetman Tony and Barrie Axtell, (2008) (updated): Quality Control in Food Processing, Technical Information Online-practical answers.mht

Thirupathi. V., Viswanathan .R. \& Devadas. CT; (2006): Science Tech Entrepreneur.

Thomas Weschler, J. Stan Bailey, Jerry Zweigenbaum and Dipankar Ghosh. (2009): food quality magazine, December/January issue.

Vautz W.; D. Zimmermann; M. Hartmann; J. I. Baumbach and J. Nolte; J. Jung. (2006): Ion mobility spectrometry for food quality and safety: Food Additives \& Contaminants: Part A: Chemistry, Analysis, Control, Exposure \& Risk Assessment, Volume 23, Issue 11, Pages 1064 - 1073.

Wilm Karl Heinz. (2003): Chemical Contaminants, Our Food; Food Safety and Control System, www.ourfood.com www.ourfood.com

XIAO Jing and MA Zhongsu: Research on Food Security Risk Early Warning under Supply Chain Environment, research sponsored by Heilongjiang Province science and technology department (Project Grant No.GA06C101-02) n.d.

Xie L, Ying Y, Ying T.( 2007): Quantification of chlorophyll content and classification of nontransgenic and transgenic tomato leaves using visible/near-infrared diffuse reflectance spectroscopy. J Agric Food Chem; 55: 4645-50.

Zayas, I.Y., Martin, C.R., Steele, J.L., Katsevich, A.( 1996): “Wheat classification using image analysis and crush force parameters", Transactions of the ASAE 39 (6), pp. 21992204. 
SCIENTIFIC, HEALTH

AND SOCIAL ASPECTS

OF THE FOOD

INDUSTRY

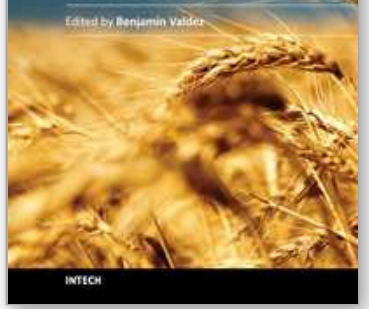

Scientific, Health and Social Aspects of the Food Industry

Edited by Dr. Benjamin Valdez

ISBN 978-953-307-916-5

Hard cover, 488 pages

Publisher InTech

Published online 01, February, 2012

Published in print edition February, 2012

This book presents the wisdom, knowledge and expertise of the food industry that ensures the supply of food to maintain the health, comfort, and wellbeing of humankind. The global food industry has the largest market: the world population of seven billion people. The book pioneers life-saving innovations and assists in the fight against world hunger and food shortages that threaten human essentials such as water and energy supply. Floods, droughts, fires, storms, climate change, global warming and greenhouse gas emissions can be devastating, altering the environment and, ultimately, the production of foods. Experts from industry and academia, as well as food producers, designers of food processing equipment, and corrosion practitioners have written special chapters for this rich compendium based on their encyclopedic knowledge and practical experience. This is a multi-authored book. The writers, who come from diverse areas of food science and technology, enrich this volume by presenting different approaches and orientations.

\section{How to reference}

In order to correctly reference this scholarly work, feel free to copy and paste the following:

Ihegwuagu Nnemeka Edith and Emeje Martins Ochubiojo (2012). Food Quality Control: History, Present and Future, Scientific, Health and Social Aspects of the Food Industry, Dr. Benjamin Valdez (Ed.), ISBN: 978-953307-916-5, InTech, Available from: http://www.intechopen.com/books/scientific-health-and-social-aspects-ofthe-food-industry/food-quality-control-history-present-and-future

\section{INTECH}

open science | open minds

\section{InTech Europe}

University Campus STeP Ri

Slavka Krautzeka 83/A

51000 Rijeka, Croatia

Phone: +385 (51) 770447

Fax: +385 (51) 686166

www.intechopen.com

\section{InTech China}

Unit 405, Office Block, Hotel Equatorial Shanghai

No.65, Yan An Road (West), Shanghai, 200040, China

中国上海市延安西路65号上海国际贵都大饭店办公楼 405 单元

Phone: +86-21-62489820

Fax: +86-21-62489821 
(C) 2012 The Author(s). Licensee IntechOpen. This is an open access article distributed under the terms of the Creative Commons Attribution 3.0 License, which permits unrestricted use, distribution, and reproduction in any medium, provided the original work is properly cited. 